\title{
SOST wt Allele
}

National Cancer Institute

\section{Source}

National Cancer Institute. SOST wt Allele. NCI Thesaurus. Code C105077.

Human SOST wild-type allele is located in the vicinity of $17 q 11.2$ and is approximately $5 \mathrm{~kb}$ in length. This allele, which encodes sclerostin protein, is involved in the negative regulation of ossification. Mutation of the gene is associated with bone dysplasias including sclerosteosis type 1, van Buchem disease and craniodiaphyseal dysplasia autosomal dominant. 